\title{
NOTES
}

\section{THE RIGHT TO A SPEEDY TRIAL AND THE EXHAUSTION REQUIREMENT OF FEDERAL HABEAS CORPUS}

By filing a petition for habeas corpus, an individual in the custody of state officials may obtain federal judicial review of his claim that such custody violates his constitutional rights. However, before any federal district court may hear a habeas corpus petition, the petitioner must have exhausted all available state remedies. ${ }^{1}$ In applying this requirement to a state prisoner alleging a denial of his right to a speedy trial, ${ }^{2}$ most federal courts initially held that the petitioner could obtain federal review of his claim, notwithstanding the fact that he had not yet been brought to trial and convicted by a state court. ${ }^{3}$ Most recently, however, federal courts addressing this question have held that a petitioner requesting discharge must present his speedy trial claim as a defense to the charges brought at his state trial before he can be deemed to have exhausted his state remedies. ${ }^{4}$

After briefly tracing the initial applications of the exhaustion requirement to habeas corpus petitioners alleging denial of their right to a speedy trial, this Note will analyze the very abrupt shift in the position taken by the federal courts on this question, emphasizing their reliance on recent Su-

1. The exhaustion requirement was first articulated in Ex parte Royall, 117 U.S. 241 (1886), and was clearly expressed in terms of federal-state comity and not as a mandatory jurisdictional requirement. The justification given for the exhaustion requirement was that it would preserve the role of state courts in the application of federal law and would also encourage orderly administration of state judicial business, preventing interruption of state adjudication by federal habeas corpus proceedings. The early decisions, although recognizing the significance of the interests of federalism served, stressed that the exhaustion requirement was not a binding rule but merely a procedure which normally should be followed. See Tinsley v. Anderson, 171 U.S. 101 (1898).

In subsequent decisions, however, as the exhaustion requirement was repeatedly applied, it came to be viewed as matter of compulsion and not one of discretion. See Brown v. Allen, 344 U.S. 443 (1953); Darr v. Burford, 339 U.S. 200 (1950); Ex parte Hawk, 321 U.S. 114 (I944) (per curiam). This restrictive application of the requirement ended, however, in Fay v. Noia, 372 U.S. 391 (1963), where the Court declared that the exhaustion rule was a matter of comity, not of jurisdiction. The requirement is thought today to be an aspect of the proper exercise of power by the federal courts and not an element of the definition of the power itself. Id. at 425 $26,434-35$ (1963).

The exhaustion requirement has been codified in 28 U.S.C. $\$ 2254$ (1970), the habeas corpus statute governing collateral attack on convictions in state courts, and has been held to apply also as a judicial doctrine in all other habeas corpus actions under 28 U.S.C. \$2241 (1970). See Fain v. Duff, 488 F.2d 218, 223 (5th Cir. 1973).

2. "In all criminal prosecutions, the accused shall enjoy the right to a speedy and public trial . . . "U.S. ConsT. amend. VI.

3. See notes 10-14 infra and accompanying text.

4. See notes 26-33 infra and accompanying text. 
preme Court dicta ${ }^{5}$ and more general considerations of federal-state comity. It will conclude that the recent case of Brown $v$. Estelle ${ }^{6}$ represents an appropriate resolution of the issues.

\section{INITIAL APPLICATION OF THE EXHAUSTION REQUIREMENT TO SPEEDY TRIAL ClaimS}

A state prisoner could not base a habeas corpus petition on an allegation that he had been demied a speedy trial until 1966, when the Supreme Court held that the right to a speedy trial was guaranteed to state defendants through the fourteenth amendment. ${ }^{7}$ Although few habeas petitions claiming deniar of a speedy trial were initially filed by state defendants, the number of such petitions increased greatly after Smith $v$. Hooey ${ }^{8}$ established the obligation of a state with charges pending against a prisoner incarcerated in another state to make a full good faith effort to bring the defendant to trial. ${ }^{9}$

The first court of appeals to apply the exhaustion requirement to a pretrial habeas corpus petition claiming denial of a speedy trial was the Fourth Circuit in Kane v. Virginia. ${ }^{10}$ The court admitted that federal habeas relief was not ordinarily available to a state prisoner before trial, but

5. The dicta which are referred to appear in Braden v. 30th Judicial Court of Kentucky, 410 U.S. 484 (1973). See notes $18-25$ infra and accompanying text.

6. 530 F.2d 1280 (5th Cir. 1976).

7. The Court held in Klopfer v. North Carolina, 386 U.S. 213 (1967), that the guarantees of the sixth amendment were included in the concept of due process required by the fourteenth amendment and as such could be extended to the states. See generally Recent Decisions, Sixth Amendment Right to Speedy Trial Applied to the States by Incorporation into the Due Process Clause of the Fourteenth Amendment, 34 BROOKLYN L. REv. 316 (1968); Note, Effect of the Right to Speedy Trial on Nolle Prosequi, 46 N.C.L. Rev. 387 (1968).

8. 393 U.S. 374 (1969). This decision concerned the plight of a prisoner incarcerated in one state with charges filed against him by another state. Before Hooey, it had been contended by the states that the state with pending charges was totally absolved from any duty under the constitutional guarantee to a speedy trial. See generally Note, Extending the Smith v. Hooey Duty to the Holding Jurisdiction, 23 MAINE L. REv. 201 (1971); Note, The State Must Make a Diligent Good Faith Effort to Obtain the Presence of an Accused for Trial When He is Incarcerated by Another Jurisdiction and Requests a Speedy Trial, 47 TEXAS L. REv. 1210 (1969).

9. 393 U.S. at 382-83. Although this case was not itself an appeal of a habeas corpus petition, the decision would greatly increase the number of speedy trial claims brought by this method. After the obligation to bring out-of-state prisoners to trial had been established, a whole new class of claimants, those prisoners against whom detainer warrants have been issued, filed habeas petitions. See Note, Habeas Corpus-An Erosion of Law and Order?, 14 CaTHOLIC LAWYER 293 (1968). See also Meyer, Effective Utilization of Criminal Detainer Procedures, 61 IOWA L. REV. 659, 677-82 (1976) (discusses the use of the right to a speedy trial to defeat detainer warrants, balancing the exhaustion requirement with the fear of providing too much aid for prosecutors).

10. 419 F.2d 1369 (4th Cir. 1970). The petition in question was filed by a prisoner incarcerated in Illinois who was also the subject of criminal indictments in Virginia, where the charges had long been pending. 
reasoned that "the peculiar nature of the right to a speedy trial requires an exception to this rule." "11 This reasoning was expressly adopted by the Ninth Circuit in Chauncey v. Second Judicial District Court of Nevada, ${ }^{12}$ in which the court held that the petitioner had exhausted his state remedies by presenting a speedy trial claim in every level of the state's judicial system, even though he had not yet been brought to trial. ${ }^{13} \mathrm{~A}$ similar result was reached by the Fifth Circuit in Beck $v$. United States, ${ }^{14}$ where the exhaustion requirement was deemed to have been met since the petitioner had presented his speedy trial claim by a writ of mandamus to both the state trial court and the state's highest court. ${ }^{15}$ The state of the law following these ${ }^{16}$

11. Id . at 1372. The court felt the nature of the right to a speedy trial to be peculiar because "denial of a speedy trial adversely affects both the prisoner's present circumstances and his ability to defend himself in the future" and stated that "only a present remedy can lift its dual oppressions." Id.

To provide future guidance to the district courts, the court concluded its opinion by stating that the state charges against a habeas corpus petitioner should be dismissed when it is proved:

1. that the prisoner demanded a speedy trial,

2. that the state nevertheless failed to make a diligent effort to obtain him for trial, and

3. that he has exhausted his state remedies ... by seeking dismissal of the charges against him because of unconstitutional delay.

Id. at 1373 .

12. 453 F.2d 389 (9th Cir. 1971). The petitioner, by state habeas corpus procedures, had sought to bar prosecution by Nevada authorities on the grounds that he had been denied his right to a speedy trial. The Nevada charges had been pending against the petitioner while he was incarcerated for several years in an Arizona prison. Id. at 390.

13. 453 F.2d at $390 \mathrm{n} .1$. According to the court, requiring the petitioner to delay federal review until after his trial would have been "an exercise in futility . . . especially when the nature of the claimed right is examined ...."Id.

14. 442 F.2d 1037 (Sth Cir. 1971). The petitioner in this case was incarcerated in a federal prison located in Texas when charges were filed against him by Texas authorities. After a detainer warrant was served upon him, the petitioner filed a writ of mandamus with the state trial court, requesting dismissal of the charges on the grounds that his right to a speedy trial had been violated. After a denial of his request by both the trial court and the Supreme Court of Texas, the petitioner requested habeas relief from the federal courts.

15. Id. at 1038. The court held simply that "the [petitioner] has exhausted the state remedies available to him," and reversed the district court, which had denied the petition for failure to satisfy the exhaustion requirement. Id.

16. In addition to these courts, it is possible that the Third Circuit also favored federal habeas review of a pretrial speedy trial claim. In United States ex rel. Jennings v. Pennsylvania, 429 F.2d 522 (3d Cir. 1970), in an opinion written by Judge Seitz, a district court's denial of a pretrial habeas petition on exhaustion grounds was vacated with instructions to review the petitioner's speedy trial claim and grant relief if warranted. This decision, however, may not have been based on the "peculiar nature" of the right to a speedy trial, as were those of the other circuits, but could possibly have been an angry reaction to a "sorry narrative of official inaction or indifference." Id. at 523. Petitioner had made innumerable efforts over several years to have the prosecutor, who did not even appear at the habeas hearing, bring him to trial. According to Judge Seitz, "the facts here alleged concerning the deprivation of the right to a speedy trial, if true, call out for something more [than denial of federal review] from a concerned judiciary." Id.

One circuit may have taken a position opposite to that reflected in the decisions discussed in the text. In Trigg v. Moseley, 433 F.2d 364 (10th Cir. 1970), the Tenth Circuit denied review 
and related district court decisions ${ }^{17}$ could be stated as follows: the exhaustion requirement of federal habeas corpus is satisfied by a state petitioner when he has presented his claim of denial of a speedy trial to all levels of the state judicial system, notwithstanding the fact that he has not yet been tried and convicted by a state court.

It was at this point in the relaxation of the exhaustion requirement that the Supreme Court decided Braden v. 30th Judicial Court of Kentucky, ${ }^{18}$ dicta from which persuaded several of the lower courts to restrict substantially the circumstances under which a pretrial habeas petitioner could obtain review of his speedy trial claim. ${ }^{19}$ Although the Court had granted certiorari in order to resolve jurisdictional problems created by a ruling many years earlier, ${ }^{20}$ the issue as to whether the petitioner had exhausted his state remedies had first to be considered and resolved in the petitioner's favor. ${ }^{21}$ The fact that the petitioner was requesting that the state of Kentucky be ordered to bring him to trial, and not that the charges be dismissed, was seen by the Court as crucial in establishing that state remedies had been exhausted:

The fundamental interests underlying the exhaustion requirement have been fully satisfied in petitioner's situation. He has already presented his federal constitutional claim of a present denial of speedy trial to the courts of Kentucky. Moreover, petitioner made no effort to abort a state proceeding or to disrupt the orderly functioning of state judicial processes. He comes to federal court not in an effort to forestall a state

of a pretrial habeas petition, stating that "the practicalities of judicial administration and the doctrine of comity . . . require that these issues [concerning the denial of the right to a speedy trial] be determined in the first instance by the state court where the charges are pending and the pertinent witnesses readily available." Id. at 366 . This decision, however, may not have been in conflict with the other circuits, as the petitioner's claim had not been presented to all levels of the state's judicial system. Id.

17. See, e.g., Evans v. Missouri, 325 F. Supp. 202 (W.D. Mo. 1969); Garrett v. Womble, 299 F. Supp. 223 (E.D.N.C. 1969); United States ex rel. Epps v. Nenna, 274 F. Supp. 508 (S.D.N.Y. 1967); contra, Smith v. Londerholm, 304 F. Supp. 73 (D. Kan. 1969).

18. 410 U.S. 484 (1973). In 1973 the petitioner was incarcerated in an Alabama state prison with criminal charges against him pending in Kentucky. For several years after his indictment on the Kentucky charges, he had without success made repeated demands that Kentucky bring him to trial.

19. See notes 68-72 infra and accompanying text.

20. See Ahrens v. Clark, 335 U.S. 188 (1948). Ahrens held that a district court could not hear a habeas corpus petition filed by a prisoner outside the court's territorial jurisdiction. The effect of the decision was to deny habeas jurisdiction to many petitioners incarcerated in another state. See Recent Decisions, Federal Jurisdiction-Habeas Corpus, 40 BROOKLYN L. REv. 475, $477-79$ (1973).

21. The petitioner faced not only the obstacle presented by the Ahrens rule but also the contention by Kentucky that state remedies would not be exhausted until the petitioner had been convicted in state court. 410 U.S. at 487 . Before reaching the Ahrens issue, the Court had to hold that a habeas corpus petitioner could request a federal court to command a state to bring him to trial. The petitioner in Braden made only this request, and did not petition for dismissal of the charges against him. Id. at 490 . 
prosecution, but to enforce [Kentucky's] obligations to provide him with a state court forum..$^{22}$

To underscore the limited nature of its holding, the Court emphasized that "nothing we have said would permit the derailment of a pending state proceeding by an attempt to litigate constitutional defenses prematurely in federal court." 23 This assurance, however, did not satisfy three dissenting Justices, ${ }^{24}$ who declared that the majority opinion was "a conversion of federal habeas corpus into a pretrial-motion forum for state prisoners.",25 Contrary to the dissenters' suggestion, however, the Braden decision has played a major role in limiting the circumstances under which a petitioner claiming denial of a speedy trial can be deemed to have exhausted his state remedies before trial.

\section{THE EMERGENCE OF THE Younger DoctRINE}

The first court of appeals after Braden to face a pretrial habeas petition alleging denial of a speedy trial was the Third Circuit in Moore $v$. DeYoung. ${ }^{26}$ The court first stated that the petitioner's claim had not been

22. Id. at 492 .

23. Id. at 494. See notes 68-72 infra and accompanying text for a discussion of how this dictum was interpreted by the lower courts in their review of habeas petitions requesting a dismissal of pending state charges.

24. Chief Justice Burger and Justices Rehnquist and Powell dissented in an opinion written by Justice Rehnquist.

25. 410 U.S. at 507 (Rehnquist, J., dissenting). The dissent maintained that the petitioner in substance was seeking to force the state to litigate a question that otherwise could only be raised as an absolute defense in a state criminal proceeding against him. $I d$. at 503 . This concern was also shared by some commentators. See, e.g., Comment, Criminal Procedure-Habeas Corpus-Federal Jurisdiction Expanded, 76 W. VA. L. REv. 236, 241 (1973).

The dissenters' concern that federal habeas review had extended too far into the pretrial stage of state proceedings was not precipitated by the Braden holding alone. Several recent Supreme Court decisions, as well as cases from the courts of appeals, had held many forms of pretrial judicial control over defendants to constitute "custody," making such defendants eligible to file petitions under 28 U.S.C. $\$ \$ 2241$ \& 2254 (1970), the federal habeas statutes. By the time Braden was decided, the following decisions had held restraints on liberty commonly used by state courts at the pretrial stage to constitute "custody": Peyton v. Rowe, 391 U.S. 54 (1968) (future sentence); Carafas v. LaValle, 391 U.S. 234 (1968) (unconditional release after petition filed); Jones v. Cunningham, 371 U.S. 236 (1963) (parole); United States ex rel. Meadows v. New York, 426 F.2d 1176 (2d Cir. 1970) (parole detainer warrant); Marden v. Purdy, 409 F.2d 784 (5th Cir. 1969) (free on bond); Burris v. Ryan, 397 F.2d 553 (7th Cir. 1968) (free on bail); United States v. Re, 372 F.2d 641 (2d Cir.), cert. denied, 388 U.S. 912.(1967) (probation).

It should also be noted that in Hensley v. Municipal Court, 411 U.S. 345 (1973), decided shortly after Braden, the Court held release on one's own recognizance to constitute "custody" under the habeas corpus statutes.

26. 515 F.2d 437 (3d Cir. 1975). The petitioner alleged that, although indicted in 1967 by a New Jersey grand jury, he had not been brought to trial as of 1973 . The petitioner had been incarcerated during this time in a Virginia prison, and all motions made on his behalf for dismissal of the charges had been denied. The petitioner's request for federal habeas relief was granted by the district court, and all state criminal proceedings were ordered to be stayed permanently. Id. at 441 . 
presented to all levels of the state's judicial system, because the state appellate courts had only denied interlocutory review of his speedy trial claim without considering the claim on its merits. ${ }^{27}$ Concluding that there had been no exhaustion of state remedies, the court next considered whether any "extraordinary circumstances" required federal review prior to exhaustion. ${ }^{28}$ The court found none, perceiving "nothing in the nature of the speedy trial right to qualify it as a per se 'extraordinary circumstance,', ,29 notwithstanding the Kane and Chauncey decisions, ${ }^{30}$ and citing Braden as

27. This ruling by the court appears highly questionable. In a decision rendered soon after the codification of the exhaustion requirement in 28 U.S.C. $\$ 2254$ (1970), the Supreme Court stated that it "did not believe Congress intended to require repetitious application to state courts." Brown v. Allen, 344 U.S. 443, 448-49 (1953). In a later case, Fransisco v. Gaithright, 419 U.S. 59 (1974), the Court confronted a situation similar to that in Moore, where the state appellate courts had denied review of a habeas petitioner's claim without considering the issue on the merits. The Court stated that:

[The state courts] had a full opportunity to determine the federal constitution issues

before resort was made to a federal forum, and the policies served by the exhaustion requirement would not be furthered by requiring resubmission of the claims to the state courts.

Id. at 63 .

Some support for the position taken by the Moore court may be found, however, in Tooten v. Shevin, 493 F.2d 173 (5th Cir. 1974), in which the Fifth Circuit held that a petition requesting review through a Writ of Prohibition, where the appellate court could change its position after trial of the petitioner, was not an adequate attempt to obtain state vindication of constitutional rights. Id. at 177. But see Eaton v. Wyrick, 528 F.2d 477, 480 (8th Cir. 1975) (not necessary for state courts to have ruled conclusively on the merits; rather, sufficient for exhaustion if state court was properly presented with the opportunity to rule); Cage v. Auger, 514 F.2d 1231, 1232 (8th Cir. 1975) (federal court may entertain proceedings where it is clear that the state court has had its opportunity to correct constitutional error); United States ex rel. Geisler v. Walters, 510 F.2d 887, 892 (3d Cir. 1975) (the exhaustion requirement does not require that the state courts have actually ruled on the merits, but merely that they have had these contentions presented to them).

28. The exhaustion requirement is not an inflexible or absolute rule. As early as Reid v. Jones, 187 U.S. 153 (1902), the Supreme Court recognized that a federal court could intervene by writ of habeas corpus in advance of the final action by the state's highest court, in "certain exceptional cases." Id. at 154. In a more recent case, Frisbie v. Collins, 342 U.S. 519 (1952), the Court emphasized that the "general rule [requiring exhaustion] is not rigid and inflexible; district courts may deviate from it and grant relief in special circumstances." Id. at 520-21.

The "exceptional circumstances" that relax the requirement of exhaustion are, by definition, rare. One example is the situation that existed in Frisbie, in which a man living in Chicago was forcibly seized, handcuffed, blackjacked, and taken to Michigan for trial. Id. at 520. The "exceptional circumstance" cited by the Court was the frequency with which such actions were gaining approval from district courts, thus necessitating expeditious review by the Supreme Court. See also United States ex rel. Richardson v. Rundle, 461 F.2d 860 (3d Cir. 1972) (district court took jurisdiction over the constitutionality of the petitioner's confinement and interrupted service of his sentence).

29. $515 \mathrm{~F} .2 \mathrm{~d}$ at 446 . The cases cited in the previous footnote seem to support the position of the Moore court in that "exceptional circumstances" in this context refer to the particular facts of each case with no particular type of claim constituting a per se "extraordinary circumstance." See Frisbie v. Collins, 342 U.S. 519, 521-22 (1952). A strong argument can be made for a per se rule, however, based on the language in Kane and Chauncey referring to the "peculiar nature" of the right to a speedy trial. See text accompanying notes 10-13 supra.

30. See notes 10-13 supra and accompanying text. 
"specifically caution[ing] that its holding should not be construed as authorizing pretrial habeas interference by federal courts in the normal functioning of state criminal processes." 31 The court could not terminate its review of the petition at that point, however, since the district court had not only ordered release of the petitioner, but had also issued an injunction staying any state criminal proceedings. ${ }^{32}$ The issuance of the injunction necessitated a consideration of Younger v. Harris ${ }^{33}$ The court concluded that Younger precluded pretrial injunction of state criminal proceedings, even in the context of a speedy trial claim, and noted the close relationship between the exhaustion requirement and the Younger doctrine. ${ }^{34}$

31. 515 F.2d at 445-46. The court emphasized that the petitioner was not seeking to enforce the state's duty to provide him with a trial, as in Braden. On the contrary, the request by the petitioner was considered to be the very attempt to abort a state trial that the dicta in Braden suggested must not be aided by federal courts. Id. at 446 .

32. 515 F.2d at 447.

33. 401 U.S. 37 (1971). This decision is the modern cornerstone of the doctrine restraining federal intervention in state judicial proceedings. The case arose when a petitioner, indicted for violation of the California Criminal Syndicalism Act, sought a federal injunction against his prosecution on the ground that such prosecution inhibited the exercise of his rights of free speech and press.

In holding that an injunction should not issue, the Court gave as justification the longstanding public policy against federal injunction of state criminal proceedings in the absence of irreparable injury both great and immediate. Id. at 46 . See text accompanying notes $48-57$ infra for a discussion of the standards to be met before federal intervention is justified.

For an exhaustive discussion of the Younger decisions and their rationale, see Comment, Post-Younger Excesses in the Doctrine of Equitable Restraint: A Critical Analysis, 1976 DuKE L.J. 523.

\section{According to the court:}

Although the doctrines of "habeas corpus-exhaustion" and "Younger-abstention" are not directly related, they share many characteristics in common. They are both predicated upon interests of federalism and comity; they both recognize exceptions for "extraordinary circumstances"; both doctrines are doctrines of judicial restraint; they both envisage adequate state remedies; and they both bar petitioners who seek to abort state prosecutions, prior to trial or final state review.

515 F.2d at 448 .

This comparison apparently has convinced at least one district court to rely directly on Younger in the habeas corpus context. Clark v. Zimmerman, 394 F. Supp. 1161 (M.D. Pa. 1975); Lovell v. Arnold, 381 F. Supp. 1047 (M.D. Pa. 1975). This court seems to have tied Younger directly to habeas corpus. The Moore holding was summarized in the Clark opinion as follows:

[A] federal court may not interfere in an ongoing state criminal prosecution in the pretrial habeas corpus context absent a showing of prosecutional bad faith or harassment or other "extraordinary circumstances" which call for the interposition of a court of equity to prevent great, immediate, and irreparable injury which is clear and imminent and for which there is no adequate remedy at law ....

$394 \mathrm{~F}$. Supp. at 1174.

It is ironic that Moore may have created this confusion and stimulated the use of Younger in the habeas context to deny review of a speedy trial claim. The irony results from Grant v. Hogan, 505 F.2d 1220 (3d Cir. 1974), which involved a petitioner who demanded dismissal of charges on speedy trial grounds without having attempted to gain state appellate review of his claim. Although the Third Circuit felt constrained to deny the petition on exhaustion grounds, it emphasized that:

If . . the Petitioner had demanded a speedy trial of the . . [state] courts . . , had moved to dismiss the charges for lack of speedy prosecution, and had sought and obtained appellate review of the denial of his motion to dismiss, habeas corpus relief might be available .... 
A similar analysis was used by the Second Circuit in United States ex rel. Scranton v. New York ${ }^{35}$ to dismiss a pretrial habeas petition alleging denial of a speedy trial. Once again the Braden dicta was invoked to refute the petitioner's assertion that the holding in Braden supported his claimed exhaustion of all state remedies. ${ }^{36}$ The relief requested by the petitioner, the court held, was completely foreclosed by the principles enunciated in Younger. ${ }^{37}$

As will be explained below, it would appear that the reliance on Younger in this situation is misplaced, for the following reasons: (1) the general doctrinal framework of which Younger is a part is one significantly different from that of habeas corpus; (2) the basic function intended for Younger may have been to allow the Court to retreat from a prior decision greatly expanding the role of federal courts in the state judicial process,

Id. at 1224 .

Although this language is of course dictum, it indicates that the Third Circuit may be the only circuit after Braden and Younger to acknowledge the power of a federal court to review a pretrial petition alleging denial of a speedy trial. The principles of Younger played no part in this earlier Third Circuit decision.

It is worth noting that the concurring judge in Moore, Judge Seitz, thought it unnecessary to consider the question of exhaustion and the effect of Younger, noting only that:

The emphasis by the Supreme Court in Braden . . ., on the fact that the petitioner

there did not seek to abort a state proceeding compels me to conclude that where, as

here, a "derailment of a pending state proceeding" is sought, intervention by a

federal court cannot be permitted.

515 F.2d at 449.

35. 532 F.2d 292 (2d Cir. 1976). The petitioner in this case, who had been indicted on a charge of murder in 1970, still had not been tried by a state court by 1975 . The state had attempted to begin trial once during this period, but a mistrial had been declared. Dismissal of all charges was requested by the habeas petition filed in federal district court. Id. at 294-95.

36. While two of the courts of appeals addressing this question after Braden have used the dicta from that decision in this way, most of the district courts have inferred a mandate from the Supreme Court that a pretrial speedy trial claim is an affirmative defense which must first be raised at state trial. See United States ex rel. Scranton v. New York, 402 F. Supp. 1010 (S.D.N.Y. 1975), aff'd, 532 F.2d 292 (2d Cir. 1976); Prock v. Dist. Court of Okla. County, 391 F. Supp. 315 (W.D. Okla. 1975); MacDonald v. Faulkner, 378 F. Supp. 573 (E.D. Okla. 1974).

The only district courts holding otherwise have been courts within the Fourth Circuit where the Kane decision has never been overruled or modified. See Crump v. Bedford County Circuit Court, 360 F. Supp. 606 (W.D. Va. 1973); Norris v. Georgia, 357 F. Supp. 1200 (W.D.N.C. 1973), modified, 522 F.2d 1006 (4th Cir. 1975). In its review of the Norris decision the Fourth Circuit discussed Braden in terms of its effect on jurisdiction and venue, but made no mention of its application to the exhaustion requirement.

37. $532 \mathrm{~F} .2 \mathrm{~d}$ at 295 . To support its position, the court quoted the following passage from Younger:

In all of these cases the Court stressed the importance of showing irreparable injury,

the traditional prerequisite to obtaining an injunction. In addition, however, the Court also made clear that in view of the fundamental policy against federal interference with state criminal prosecutions, even irreparable injury is insufficient unless it is "both great and immediate... " Certain types of injury, in particular, the cost, anxiety, and inconvenience of having to defend against a single criminal prosecution, could not by themselves be considered "irreparable" in the special legal sense of that term. Instead, the threat to the plaintiff's federally protected right must be one that cannot be eliminated by his defense against a single criminal prosecution.

Id. at 295-96 (quoting Younger v. Harris, 401 U.S. 37, 46 (1971)). 
while at the same time retaining some flexibility; and (3) a state which has denied a prisoner his right to a speedy trial is not entitled to the deference Younger extends in the name of federal-state comity.

As has been pointed out in recent decisions, Younger involved a suit for a federal injunction against state proceedings, not a petition requesting habeas corpus relief. ${ }^{38}$ The importance of this distinction is that it establishes the general context in which Younger was decided and bears on the justification for the holding. It should be noted that the issuance of injunctions by federal courts against state proceedings is forbidden by statute, except in very limited circumstances. ${ }^{39}$ Any reluctance by federal courts to issue an injunction against a state criminal prosecution therefore results not only from a high regard for federal-state comity, but also from the prohibition imposed by statutory law. ${ }^{40}$ The contrast with habeas corpus proceedings is apparent, for habeas is a form of relief guaranteed by the Constitution, ${ }^{41}$ provided for expressly by statute, ${ }^{42}$ and historically construed broadly by the courts. ${ }^{43}$

38. The dissenting judge in Chauncey v. Second Judicial Dist. Court of Nev., 453 F.2d 389 (9th Cir. 1971), see notes 12-13 supra and accompanying text, contended that the Younger holding disapproved the interference with the state sanctioned by the majority. The majority, however, replied that the case before them was not a suit for an injunction or declaratory judgment, but a habeas corpus proceeding under 28 U.S.C. $\$ 2241$ (c)(3) (1970). Id. at 390 n.1.

39. 28 U.S.C. $\S 2283$ (1970), often referred to as the Anti-Injunction Statute, reads as follows: "A court of the United States may not grant an injunction to stay proceedings in a State court except as expressly authorized by Act of Congress, or where necessary in aid of its jurisdiction, or to protect or effectuate its judgments." It would appear that the statute's prohibitions are absolute but for its express exceptions, and that its provisions rest upon the power of Congress and not notions of comity. See Atlantic Coast Line R.R. v. Brotherhood of Locomotive Eng'rs, 396 U.S. 1201 (1970); Comment, Federal Courts-Federal Anti-Injunction Statute-Injunctions in Federal Courts to Stay Proceedings in State Courts Must Be Within One of the Statutory Exceptions to the Federal Anti-Injunction Statute, 46 NOTRE DAME LAW. 616 (1971).

40. The Anti-Injunction Statute may be seen as a statutory embodiment of traditional judicial concern for the principles of comity and federalism, and an effort to maintain the delicate balance between those principles and individual constitutional interests. See Comment, Exceptions to the Anti-Injunction Statute: The Power of Federal Courts to Enjoin Bad Faith Enforcement of Unconstitutional State Statutes Where a State Proceeding Is Pending, 21 AMERICAN U.L. REv. 395, 396 (1972). It was also stressed by a member of the Younger majority that intervention by a federal court when the Younger requirements are met is still subject to any further limitations that may be placed on such intervention by the Anti-Injunction Statute. 401 U.S. at 56 n.3 (Stewart, J., concurring). See Mitchum v. Foster, 407 U.S. 225 (1972) (requirements of Younger must be fulfilled even though action brought falls under one of the exceptions to the Anti-Injunction Statute).

41. The writ of habeas corpus may not be suspended, "unless when in Cases of Rebellion or Invasion the public safety may require it." U.S.ConST. art. I, $\S 9, \mathrm{cl}$. 2. See also C. WRIGHT, LAW OF FEDERAL COURTS $\$ 10$ (3d ed. 1976), where the author suggests that the broad reach of habeas corpus may even be beyond the power of Congress to limit.

42. Habeas corpus relief is the subject of 28 U.S.C. $\$ 2241$ (1970), governing pretrial relief, and 28 U.S.C. $\$ 2254$ (1970), which applies to post-conviction remedies. See note 1 supra for a discussion of these statutes and their relation to the exhaustion requirement.

43. The great breadth of the federal courts' power of independent adjudication of habeas 
The statutory limitations on the power of federal courts to issue injunctions, together with one particular attempt by the Supreme Court to avoid these limitations, also explain the basic need for the Younger decision, and suggest the purpose behind the principles articulated in that decision. While Congress had provided certain statutory exceptions to the AntiInjunction Statute, there were few other ways to avoid the statute's application until the Court decided Dombrowski v. Pfister. ${ }^{44}$ That case held that the Anti-Injunction Statute did not apply in situations where no state prosecutions were pending, and that a federal court could strike down state statutes unconstitutional on their face. ${ }^{45}$ This left open the question of whether federal injunctions could issue to forbid prosecution under an unconstitutional state statute when state proceedings had already been instituted. ${ }^{46}$ To stem the ensuing flood of pleas for intervention by federal courts ${ }^{47}$ the Court was forced to limit in some way the relief authorized by Dombrowski. The Court did this not by use of the Anti-Injunction Statute, but by resort to the traditional prerequisites for equitable relief from the judicial system. The use of these prerequisites-the threat of irreparable injury and the lack of an adequate remedy at law-was said by the Court to be justified also by notions of federal-state comity. ${ }^{48}$ The courts in Moore and Scranton applied

corpus stems from the very nature and history of the writ. See generally Fay v. Noia, 372 U.S. 391 (1963).

Although the recent decision of Stone v. Powell, 428 U.S. 465 (1976), discussed in notes 7779 infra, excluded fourth amendment claims from the scope of habeas corpus review, that ruling would appear to be based on the nature and purpose of the exclusionary rule, and may not indicate an end to broad construction of habeas jurisdiction.

44. 380 U.S. 479 (1965). The defendant was an organization active in fostering civil rights for blacks in Louisiana. It brought suit to request an injunction against the operation of the Louisiana Subversive Activities and Communist Propaganda Control Law, on the ground that the statute by its terms violated the first amendment. The three-judge district court dismissed the complaint, holding that there had been no presentation of threatened irreparable injury to federal rights which warranted cutting short the normal adjudication of constitutional defenses in state criminal proceedings.

45. Id. at 484 n.2, 491-92. Although the majority opinion did not state specifically that the Anti-Injunction Statute was inapplicable in all such situations, it would appear that this case presented a situation where the Statute did not apply, and was not a case where a judicial exception was engrafted upon the Statute. See Reaves, The Federal Anti-Injunction Statute in the Aftermath of Atlantic Coast Line Railroad, 5 GA. L. REv. 294 (1971).

46. This question was of necessity left open since no criminal proceedings had yet been instituted by Louisiana, although there was evidence of threats of suit by state officials. See generally Shevin, Federal Intrusion in State Court Proceedings, 1972 Utah L. Rev. 3.

47. Although most Supreme Court decisions granting relief in a case involving federal intervention in state criminal proceedings produce large increases in the number of related petitions, the increase after Dombrowski was particularly significant. See Recent Cascs, Injunctions-Federal Courts May Not Enjoin State Criminal Proceedings Unless Irreparable Injury is Shown From Harassment in the Prosecution of Patently Unconstitutional Statutes, 40 U. CiN. L. REV. 613, 617-18 (1971).

48. 401 U.S. at $43-45$. Three distinct requirements are suggested by the Court which must be met by a plaintiff before he may successfully seek a federal injunction of state criminal proceedings. First, he must meet the traditional equitable standards, that is, irreparable harm is 
these principles in considering the harm suffered by a state defendant during the defense of a criminal prosecution, ${ }^{49}$ and use them to support their dismissal of pretrial habeas petitions containing speedy trial claims. ${ }^{50}$ It could therefore be argued that use of the equitable prerequisites in the habeas corpus context is improper when one considers that the prerequisites may have been used by the Younger Court, rather than the Anti-Injunction Statute, in order to retain a large degree of discretion over the issuance of injunctions. ${ }^{51}$ The distinction between habeas and injunctive relief was thus ignored by these courts.

It is also instructive to examine the interests and policies on which the Younger opinion rested. According to the Court, the Younger holding was based partly on the basic doctrine that courts of equity should not exercise their extraordinary powers when the moving party has an adequate remedy at law and will not suffer irreparable injury if denied equitable relief. ${ }^{52}$ One of the policies protected by this doctrine, that of preventing any erosion of the role of a jury, ${ }^{53}$ has no relevance in the habeas context, as there is no role whatsoever provided for a jury. ${ }^{54}$ Another concern of this equitable doctrine, that of avoiding any duplication of legal proceedings and legal sanctions, ${ }^{55}$ is not present in the exercise of habeas jurisdiction, since duplication was obviously contemplated by Congress, whether federal review occurs after conviction in the state court ${ }^{56}$ or before a state court has rendered

threatened and no adequate remedy at law exists to protect him. Second, his situation must fall within one of the statutory exceptions to the Anti-Injunction Statute. Finally, he must demonstrate prosecutorial bad faith or harassment on the part of state officials or other extraordinary circumstances. Id. All these requirements rest upon the fundamental policy against federal intervention in state criminal proceedings, absent truly extraordinary circumstances. See C. WRIGHT, note 41 supra, \& 52 (3d ed. 1976); Comment, Federal Abstention-A Restrictive Interpretation of the Dombrowski Doctrine, 17 N.Y.L.F. 652 (1971); Recent Developments, Federal Courts- $R_{x}$ for Federal Anticipatory Relief in State Criminal Proceedings, 51 WASH. L. Rev. 209, 215 (1975).

49. 401 U.S. at 46 . The harm suffered by the defense of a single criminal prosecution is not "irreparable harm" sufficient to justify federal equitable relief. See note 34 supra where the complete passage of the opinion appears.

50. See United States ex rel. Scranton v. New York, 532 F.2d 292, 295-96 (2d Cir. 1976); Moore v. DeYoung, 515 F.2d 437, 448 (3d Cir. 1975).

51. See Gilbert, Questions Unanswered by the February Sextet, 1972 UTAH L. Rev. 14, 18 (1972). The Court may also have wished to retain this discretion in order to be able to adjust the relationship between the state and federal courts as its own composition shifts with fluctuations in the political climate. See Whitten, Federal Declaratory and Injunctive Interference with State Court Proceedings: The Supreme Court and the Limits of Judicial Discretion, 53 N.C.L. REv. 591 (1975), for an argument that this is a discretion which the Court is not entitled to exercise.

52. 401 U.S. at $43-45$.

53. Id. at 44 .

54. The writ of habeas corpus ad subjiciendum is by definition a judicial order directing a government official to bring a person within his custody before the court, for an inquiry into the legality of that custody. See Fay v. Noia, 372 U.S. 391, 399-415 (1963).

55. 401 U.S. at 44.

56. See 28 U.S.C. $\$ 2254$ (1970), which governs collateral attack on convictions finally rendered. 
judgment. ${ }^{57}$ In fact, it is the collateral-and inherently duplicative-nature of habeas relief which makes it a powerful constitutional guarantee against unlawful incarceration.

A stronger argument, however, for reliance on Younger is the substantial identity of the two doctrines' concern for the relationship between the federal and state judiciaries. The holding in Younger was motivated most significantly by considerations of "comity" and "Our Federalism." A proper respect for state functions was required of the federal courts, based on a recognition that "the entire country is made up of a Union of separate state governments, and . . . [that] the National Government will fare best if the States and their institutions are left free to perform their separate functions in their separate ways." 58 The judicial doctrine of exhaustion was founded on a similar concern for the role that state courts were felt to play in the vindication of federal rights. ${ }^{59}$ These and other similarities between the two doctrines have been emphasized by many courts, ${ }^{60}$ and recent Supreme

57. See 28 U.S.C. $\$ 2241$ (1970), which provides for habeas corpus relief in thc absence of any final action by a state court.

58. 401 U.S. at 44. Although the Court in Younger "merged" the two concepts, "comity" and "Our Federalism" had traditionally been considered and applied separately. "Comity" was defined as the duty of respect owed by federal courts to state courts, arising from the principle that state courts share with federal courts the solemn responsibility of guaranteeing constitutional rights. "Our Federalism," however, was considered to be a broader concept, requiring federal courts to protect federal rights in a manner that would not unduly interfere with the legitimate activities of the states. See The Supreme Court, 1974 Term, 89 HARV. L. REv. 1, 151 n.2 (1975); Comment, note 33 supra, at 530 n.28. There is perhaps little lost in the merging of the two concepts, in that comity appears merely to be the duty of respect arising from recognition of "Our Federalism."

59. See Tinsley v. Anderson, 171 U.S. 101 (1898), and Ex parte Royall, 117 U.S. 241

(1886). See also note 1 supra.

60. In Schlesinger v. Councilman, 420 U.S. 738 (1975), the Supreme Court discussed the two doctrines in dismissing a suit by a serviceman to enjoin his court martial proceedings. According to the Court:

[C]onsiderations of comity [and] the necessity of respect for coordinate judicial systems .... have led this Court to preclude equitable intervention [unless Younger requirements are met] . . . Precisely these considerations underlie the requirement that petitioners seeking habeas relief from state criminal convictions must first exhaust available state remedies.

Id. at 756.

See also Dolack v. Allenbrand, 548 F.2d 891, 893 (10th Cir. 1977) (both doctrines based on comity-Younger applied in habeas context, distinctions between the two not of great significance); Tatzel v. Hanlon, 530 F.2d 1205, 1206 (5th Cir. 1976) (the same policy considerations underlie both doctrines); Moore v. DeYoung, 515 F.2d 437, 448 (3d Cir. 1975) (language cited in note 34 supra); Theriault v. Lamb, 377 F. Supp. 186, 188 (D. Nev. 1974).

The very close relationship between the two doctrines is also made clear by another recent decision, Huffman v. Pursue, Ltd., 420 U.S. 592 (1975). In that case, the Court not only extended the application of Younger to injunction against state civil proceedings, but held that the Younger standards must be met to justify federal intervention where the losing litigant has not exhausted his state appellate remedies. Id. at 607-09. This holding, although illustrating the Court's strong bias against federal intervention in yet another setting, would not seem to affect directly the resolution of a speedy trial claim in a habeas case, since the cases under discussion in this Note involve petitioners who have exhausted their state appellate remedies. 
Court decisions have greatly expanded the areas to which Younger applies, affirming that doctrine's continued vitality ${ }^{61}$ But regardless of the strength of this argument in favor of Younger's application to the habeas context in general, there are several considerations which militate strongly against the use of Younger to deny pretrial habeas review of a speedy trial claim. ${ }^{62}$

First, the principle of comity relied on by Younger insures that federal courts will not, by their interference with state courts, convey a mistrust of the state courts' ability to resolve constitutional claims. ${ }^{63}$ There is, however, certainly a question as to whether a state court or its criminal justice system deserves any deference when it has not complied with the constitution's mandate to grant the defendant a prompt hearing. In much the same way, the concept of "Our Federalism" promotes a significant state interest by discouraging the federal courts from unduly disrupting the smooth functioning of the state's judicial system. Again, however, an argument that a state's judiciary is functioning smoothly is a hard one to make in the face of a petitioner's long incarceration without trial. ${ }^{64}$

61. This continued vitality of the Younger doctrine, especially as viewed through Schlesinger, was specifically relied on by the Second Circuit in Scranton. See 532 F.2d at 296.

62. Most courts that have applied Younger to deny review of a speedy trial claim have done so by citing the portion of that opinion which states that "the threat to the plaintiff's federally protected rights must be one that cannot be eliminated by his defense against a single criminal prosecution" for there to be "irreparable injury." 401 U.S. at 46. See United States ex rel. Scranton v. New York, 532 F.2d 292 (1976), and text accompanying notes 35-37 supra. The concept that the "irreparable injury" requirement is not satisfied simply because the accused must defend a criminal prosecution actually dates from cases well before Younger. See Douglas v. City of Jeannette, 319 U.S. 157 (1943); Fenner v. Boykin, 271 U.S. 240 (1926).

63. The fact that this concern exists is one reason that federal intervention in a state proceeding is considered so disruptive of good working relationships between the federal and state judicial systems. By intervening, the federal court is implying that the state court is not sufficiently competent to comprehend and apply federal constitutional law. See Recent Developments, The Availability of Federal Relief When No State Prosecution Is Pending, 19 ST. Louis U.L.J. 419, 426 (1975).

64. Indeed, it can also be argued that the Younger doctrine itself contains exceptions which answer directly the concern that there exists an adequate and effective state forum.

One situation in which Younger will not compel a dismissal is one in which there is present any "bad faith" or "harassment" by the state. See Younger v. Harris, 401 U.S. 37, 48 (1971). Later decisions indicate that federal courts may find such a situation to exist where there is an invocation of the criminal process without any hope of ultimate success. See Allee v. Medrano, 416 U.S. 802 (1974). Another situation which will lead to avoidance of a Younger dismissal is the presence of "extraordinary circumstances," such as a statute "flagrantly and patently" unconstitutional, for which there exists no possibility of constitutional application. See Younger v. Harris, 401 U.S. 37, 53-54 (1971); Hernandez v. Danaher, 405 F. Supp. 757 (N.D. Ill. 1975), prob. juris. noted, 96 S. Ct. 2622 (1976) (unconstitutional Attachment Act); Nihiser v. Sendak, 405 F. Supp. 482 (N.D. Ill. 1974), vacated, 423 U.S. 976 (1975) (statute allowing confiscation of materials without judicial determination of obscenity).

In summary, the presumption that state officials will adequately protect federal constitutional rights exists only where prosecution is undertaken in good faith without harassment, and in the absence of any other extraordinary circumstances. A failure by the state to so act indicates that only federal intervention remains to vindicate a defendant's constitutional rights. See Casey, Federal Court Intervention in State Criminal Prosecutions, 56 MAss. L.Q. 11 (1971); 
It should also be pointed out that the application of Younger in this context is contrary to the rationale for a traditional exception to the habeas corpus exhaustion requirement. In appropriate cases, inordinate delay in a state's judicial process may preclude a state from relying on the exhaustion requirement to defeat federal review, on the premise that the state has by its delay rendered any possible remedy ineffective to protect the petitioner's rights, whether the delay occurs before ${ }^{65}$ or after ${ }^{66}$ final conviction. ${ }^{67}$

A strong argument can thus be made that Younger and its progeny should not be applied to bar an injunction against further state criminal prosecution of a defendant who has been denied his right to a speedy trial. The most recent solution to this habeas corpus problem, however, does not address the issue.

\section{THE BRADEN DICTA: JUdICIAL COMPROMISE OR REMEDY TO FIT THE VIOLATION?}

The most recent application of the exhaustion requirement to a habeas petition alleging denial of a speedy trial was Brown v. Estelle,${ }^{68}$ decided by

Note, Declaratory Judgments: Federal Anticipatory Relief from State Criminal Statutes After Steffel v. Thompson, 50 IND. L.J. 567, 577 (1975).

Perhaps the strongest evidence of the Younger doctrine's requirement of an adequate and effective state forum as a prerequisite to its application is found in Gibson v. Berryhill, 411 U.S. 564 (1973), when the Court upheld the injunction of a State Board of Optometry hearing:

Younger v. Harris contemplates the outright dismissal of the federal suit, and the presentation of all claims, both state and federal, to the state courts. Such a course naturally presupposes the opportunity to raise and have timely decided by a competent state tribunal the federal issues involved.

Id. at 577 (emphasis added).

65. See Rheuark v. Wade, 540 F.2d 1282 (5th Cir. 1976); Cottman v. Donnelly, 398 F. Supp. 1086, 1090 (D. Mass. 1975).

66. See, e.g., Sapienza v. Vincent, 534 F.2d 1007, 1010 (2d Cir. 1976); Reynolds v. Wainwright, 460 F.2d 1026, 1027 (5th Cir. 1972). This exception to the exhaustion requirement appears to be one particular application of the general principle that where there are any circumstances which render a state's corrective process ineffective to protect a prisoner's rights or which indicate that further pursuit of a remedy would be an exercise in futility, habeas corpus relief may be granted. See, e.g., Cage v. Auger, 514 F.2d 1231, 1232 (8th Cir. 1975); Terry v. Wingo, 454 F.2d 694, 695 (6th Cir. 1972); Franks v. Johnson, 401 F. Supp. 669, 670 (E.D. Mich. 1975).

67. This points out yet another similarity, albeit an unfortunate one, between the Younger doctrine and the exhaustion requirement: when a state court does not allow an individual to present his claims, or provides a forum that does not render its decision on his claims with reasonable dispatch, any invocation of Younger or the exhaustion requirement serves only to shield an invasion of the petitioner's rights. See generally Palmer v. Judge and District Attorney of the 13th Judicial Dist. of Tenn., 411 F. Supp. 1029 (W.D. Tenn. 1976). This opinion is either a very courageous or a remarkably uninformed decision, for it granted a pretrial petition containing a speedy trial claim with no reference either to the warnings in Braden or the principles of Younger. When confronted by the state's contentions that the federal court should refrain from acting since the petitioner could present his speedy trial claim at his trial, the court stated: "The fact that the state may finally be ready to move when the federal court raises its hand is no cure for the infection and potentially irreparable injury wreaked by the delay." Id. at 1034 (quoting United States ex rel. Hill v. Deagan, 268 F. Supp. 580 (S.D.N.Y. 1967)).

68. $530 \mathrm{~F} .2 \mathrm{~d} 1280$ ( 5 th Cir. 1976). The petitioner was incarcerated in a Texas state prison at 
the Fifth Circuit. The issue considered by the court was stated simply as "whether petitioner has any right to invoke federal habeas corpus in view of the fact that he has not yet been tried on the indictment . . . ."69 In holding that the petitioner had not exhausted his state remedies, the court denied relief on the basis of the distinction made by Braden between a petitioner who seeks to abort a state proceeding and one who seeks only to enforce the state's obligation to bring him promptly to trial. ${ }^{70}$ According to the court, the distinction should be made on the basis of the type of relief sought: an attempt to dismiss an indictment or otherwise to prevent a prosecution is an effort to abort a state proceeding, while an attempt to force the state to go to trial is an attempt to enforce a valid obligation of the state. ${ }^{71}$ To justify its holding that dismissal of the charges is an objective not obtainable through federal habeas corpus, the court stated that:

[A] claim that indictments should be dismissed because of an already accomplished violation of a speedy trial right amounts to an attempt to assert an affirmative defense to a state criminal charge prior to a judgment of conviction by a state court. ${ }^{72}$

The court based its holding strictly on the guidance provided by Braden, with no attempt to rely on the Younger principles of federalism and comity. The court's analysis separated violations of the right to a speedy trial into two categories: a present denial of the right, which a federal court may remedy by commanding the state to bring a prisoner to trial, and a past or completed denial of the right, which is an affirmative defense that must be litigated at trial before consideration by the federal courts.

the time he filed for habeas relief. While serving a sentence for armed robbery, the petitioner learned of the existence of two assault-related charges against him outstanding in a Texas county. After various attempts over a period of two years to have these charges brought to trial, the petitioner filed a motion to dismiss based on a speedy trial claim. After this motion was denied by the trial court and all Texas appellate courts, the petitioner requested federal habeas relief under 28 U.S.C. \$ 2241 (1970).

Particular attention should be paid to the analysis used by this court as it is the only circuit which has changed its position on the speedy trial issue since the Braden decision. See notes 1415 supra and accompanying text for a discussion of the Fifth Circuit's previous position, articulated in Beck v. United States, 442 F.2d 1037 (5th Cir. 1971).

69. 530 F.2d at 1282 . The petition filed with the district court definitely requested a dismissal of the charges pending in state court but was also deemed by the court to request that, in the alternative, the state should be forced to begin trial. Due to this construction of the petition, the court ruled that the petition would be subject to review as a claim of present denial of a speedy trial, provided the petitioner followed certain detailed state procedures. Id. at 1283 . See text accompanying notes 73-85 infra for a discussion of the distinction between claiming a present denial and a past denial.

70. Id at 1283-84. The distinction discussed by the Brown court may be found in Braden v. 30th Judicial Court of Ky., 410 U.S. 484, 491-93 (1973). See notes 73-85 infra and accompanying text.

71. Id. at 1283. See Tooten v. Shevin, 493 F.2d 173, 176 (5th Cir. 1974), cert. denied, 421 U.S. 966 (1975), where this argument is applied to a petitioner requesting habeas relief from prosecution under an allegedly unconstitutional state statute.

72. $530 \mathrm{~F} .2 \mathrm{~d}$ at 1283 (emphasis added). 
This subdivision of the right to a speedy trial can be seen as the result of a judicial compromise. One alternative would have been to hold that the exhaustion requirement could be met only after all affirmative defenses, including a speedy trial claim, had been presented at state trial and a conviction returned. ${ }^{73}$ This alternative clearly would have been unacceptable, however, since the constitutional right to a speedy trial could be defeated by a state court's refusal ever to bring a prisoner to trial. ${ }^{74}$

The other alternative would have been to allow review of a speedy trial claim after such claim had been presented by motion at all levels of the state judicial system, whether or not the petitioner was requesting dismissal of the charges or simply demanding a trial. This view represented the state of the law prior to Braden, but proved unacceptable to the court in that decision. ${ }^{75}$

An examination of several other recent decisions ${ }^{76}$ indicates the reason this alternative has been rejected: the scope of habeas corpus, characterized as a "serious intrusion on values important to our system of government," 77 has undergone a general constriction. ${ }^{78}$ It has been suggested that this

73. This alternative may have been suggested to some extent by the Ninth Circuit in Drury v. Cox, 457 F.2d 764 (9th Cir. 1972), where the court implied that Younger compels state finality on all issues presented by a case before a habeas petition may be considered. See note 38 supra for an argument that this implication was not intended by the court.

74. Obviously, if federal habeas review cannot take place until after trial of the prisoner, the state could thwart any federal review simply by not bringing the prisoner to trial. Of course, the petitioner would argue in such a case that the exhaustion requirement should be waived because of "extraordinary circumstances," see note 28 supra, or the lack of an effective state forum, see note 66 supra.

75. See notes 10-18 supra and accompanying text.

76. See, e.g., Stone v. Powell, 428 U.S. 465 (1976) (fourth amendment claim not required to be heard by federal court in habeas review if state has provided full and fair adjudication of claim); Francis v. Henderson, 425 U.S. 536 (1976) (unintended failure to comply with state procedural waiver rule bars federal review of the issue); Presier v. Rodriguez, 411 U.S. 475 (1973) (exhaustion required in civil rights action by state prisoner); Boyd v. Dutton, 405 U.S. 1 (1972) (burden on petitioner to disprove state court factual determinations); Picard v. Connor, 404 U.S. 270 (1971) (no exhaustion if state courts have not had first opportunity to hear claim); McMann v. Richardson, 397 U.S. 759 (1970) (guilty plea a waiver of any pretrial deficit).

77. Stone v. Powell 428 U.S. 465,491 n.31 (1976).

78. This development is best understood in terms of the political climate surrounding the Court and the resulting decisions affecting the scope of federal review of state criminal prosecutions. During the 1960's, the expansion of rights for criminal defendants and the extension of these rights to state defendants stimulated political concern for "law and order," and eventually led to the appointment of several Justices who were described as "strict constructionists." See Miller \& Shepard, New Looks at an Ancient Writ: Habeas Corpus Reexamined, 9 U. RICHMOND L. REv. 49, 68-69 (1974), for a discussion of the effects of these cries for "law and order" upon federal intervention in state proceedings. The net result of this political trend and series of appointments appears to have been a gradual withdrawal by the federal courts from the enforcement of constitutional rights guarantced to state defendants. Indeed, "federal-state comity" and "principles of federalism" may serve as an excuse for stripping federal courts of jurisdiction conferred by Congress in order to protect constitutional rights. See Francis v. Henderson, 425 U.S. 536, 548-51 (1976) (Brennan, J., dissenting). But see Comment, Federal Intervention in State Criminal Proceedings: Inadequate Remedies in Ade- 
constriction, in turn, is a result of a reluctance of the Court to grant habeas relief for "non-'guilt-related' constitutional violations."79

The compromise by subdivision of the right appears to be one which guarantees that a state prisoner will not remain imprisoned indefinitely without a trial, yet one which also gives the state a last opportunity to fulfill its constitutional responsibility before a federal court completely divests the state of its control over the prisoner. This compromise, which has resulted from the interplay between concern for basic enforcement of the speedy trial right and a general decision to constrict the scope of federal review of state decisions, is not itself immune from criticism. The courts now applying this compromise are in reality granting a form of relief which has traditionally been considered to be inadequate for the violation of the right to a speedy trial. The absolute and complete discharge of a prisoner has been considered the only effective remedy ${ }^{80}$ because prosecutors, who were free to commence another prosecution after the speedy trial claim had been sustained, would not be deterred from causing undue delay in the future. ${ }^{81}$ The remedy now applied, that of requiring trial by the state within a reasonable time, had been previously suggested as appropriate by Justice Harlan in his dissent in Smith $v$. Hooey. ${ }^{82}$ The majority of the present Court, however, had recently

quate Forums, 63 GEO. L.J. 1143 (1975) (suggesting that the Court is properly reconciling the state's legitimate interest in the enforcement of its criminal laws and the federal courts' role as the primary guardian of federal constitutional rights).

79. Stone v. Powell, 428 U.S. 465,516 (1976) (Brennan, J., dissenting). The reduction in the scope of federal habeas corpus review may be based on this factor rather than concerns for notions of federal-state comity. The cases cited in note 76 supra may be the groundwork for a drastic withdrawal of federal habeas jurisdiction for non-guilt related detention, although such detention may be unconstitutional. See id . at 516-17 (1976) (Brennan and Marshall, JJ., dissenting).

80. Most state statutes providing a detailed plan for the enforcement of a defendant's right to a speedy trial dismiss all charges if that right has been violated and bar any subsequent prosecution on those charges. See, e.g., FLA. R. CRIM. P. 3.191(h)(1); N.Y. CODE CRIM. Pro. § $210.20(1)(\mathrm{g})(4)$ (McKinney 1971). But see 18 U.S.C. $\$ 3162$ (Supp. IV 1974), the Speedy Trial Act of 1974, which provides that if a prisoner is not tried according to the time limits set by the Act, the court may dismiss with or without prejudice, depending on the seriousness of the offense, the facts which led to the dismissal, and the impact of a reprosecution on the administration of justice. This statute, however, is not used as a standard for interpreting the sixth amendment. See United States v. MacDonald, 531 F.2d 196, 204 n.15 (4th Cir. 1976). See notes 82-83 infra and accompanying text for a discussion of the constitutional remedies considered by the Court to be available.

81. Dismissal with prejudice would seem to be a necessary element of any scheme that purports to place an affirmative duty on the state to comply with the requirements of the right to a speedy trial. See Kane v. Virginia, 419 F.2d 1369 (4th Cir. 1970), discussed at notes 10-11 supra and accompanying text; American Bar Association, Standards Relating to SPEEdy TrIal-APproved Draft 40 (1968); Poulos \& Coleman, Speedy Trial, Slow Implementation: The ABA Standards in Search of a Statehouse, 28 HASTINGs L.J. 357 (1976); Note, The Right to a Speedy Criminal Trial, 57 Colum. L. Rev. 846, 866 (1957); Note, Speedy Trial Schemes and Criminal Justice Delay, 57 CORNELl L. REv. 794 (1972).

82. 393 U.S. 374, 384 (1968) (Harlan, J., dissenting). Justice Harlan argued that a decision holding that the right to a speedy trial had been violated should not result in the automatic 
stated that although the remedy of dismissal is a very serious and severe one, "it is the only possible remedy." 83

While the above language would seem to prohibit the remedy applied in Braden, a closer analysis indicates that such a remedy will quite adequately serve to protect the right to a speedy trial. According to the Court, the guarantee of a speedy trial is an important safeguard which prevents "undue and oppressive incarceration prior to trial . . . and [limits] the possibility that long delay will impair the ability of an accused to defend himself." 84 In a very real sense, the interest served by the guarantee of a speedy trial may therefore be insured by two different remedies. The "undue and oppressive incarceration prior to trial" may be alleviated by requiring the state to bring a habeas petitioner to trial, and the prejudice to his defense may be cured after he has suffered a conviction (and the prejudice to his defense has become apparent $)^{85}$ by ordering a dismissal of all charges.

\section{CONCLUSION}

Although federal courts initially demonstrated a willingness to review a habeas corpus petition claiming denial of a speedy trial notwithstanding the fact that the petitioner had not yet been convicted by any state court, that position was substantially changed by the combined force of two significant events. The Supreme Court's decision in Braden suggested that a habeas petitioner requesting dismissal before trial had not exhausted his state remedies, and the Younger doctrine of federal-state comity was expanded to apply in many areas related to the exercise of habeas jurisdiction. Although the reliance upon Younger to justify a holding that exhaustion had not occurred may be misplaced, it is apparent that the change in this state of the law can be justified by considering Braden to be an attempt to fashion a remedy more responsive to the interests served by the right to a speedy trial.

dismissal of the charge. Instead, the Court should require the state to prosecute within a reasonable time or forfeit that right. See also Yoo Kun Wha v. Sheriff of Fulton County, 436 F.2d 966 (3d Cir. 1970) (adopting Justice Harlan's approach in Hooey).

83. Barker v. Wingo, 407 U.S. 514, 522 (1972). The Court considered the remedy of dismissal to be unsatisfactorily severe, since a defendant who may be guilty of a serious crime will go free, without ever having been tried. Id. The Court pointed out, however, in Strunk v. United States, 412 U.S. 434, 439 (1973) (unanimous decision), that the denial of the right is unlike the denial of other rights, such as those guaranteed by the fourth and fifth amendments, which can be cured by providing a new trial or excluding certain evidence. The Court reaffirmed in that case that "in light of the policies which underlie the right to a speedy trial, dismissal must remain, as Barker noted, the only possible remedy." 412 U.S. at 440.

84. United States v. Ewell, 383 U.S. 116, 120 (1966).

85. Indeed, in determining whether there has been a violation of the right to a speedy trial, the prejudice to the petitioner's defense is a factor to be considered, along with the length of delay, the reason for the delay, and the defendant's assertion of his right. See generally Barker v. Wingo, 407 U.S. 514 (1972) and United States v. MacDonald, 531 F.2d 196 (4th Cir. 1976). 
The remedy fashioned, requiring a state to bring a defendant to trial rather than dismissing the charges, is the result of a compromise: the remedy to be applied adequately safeguards the basic interests served by the right to a speedy trial, yet is consistent with the Court's present reluctance to continue federal interference with state adjudication of federal constitutional rights. 